\title{
Establishment of winter versus spring aerial seedings of domestic grasses and legumes on logged sites
}

\author{
B.M. BROOKE AND F.B. HOLL
}

\section{Abatract}

Forage grasses and legumes were sown on clearcut-logzed sites near Kamloops, B.C., to increase range productivity in the interval before the forest canopy closed. Seed was broadcast by aeroplane during the winter when these sites were snow-covered. On clearcuts above 1,000 m elevation 5 species were used: orchardgrass (Dactylis glomerata L.), timothy (Phleum pratense L.), smooth brome (Bromus thermis Leyss.), aloike clover (Trifollum hybridum L.), and white clover ( $T$. repens L.). The objective of this study was to determine the effect of seeding date on the establishment and survival of these grasses and legumes. A survey of existing operational winter seedings produced establishment estimates (percent of live seeds sown that resulted in established plants) for orchardgrass of $2.3 \%$; timothy, $1.2 \%$; and brome, $1.3 \%$; in contrast to $0.1 \%$ for the clover species. On operational spring seedings grass establishment was 1.3, 0.5 , and $1.9 \%$ respectively for the first 3 species while clover was $2.6 \%$. In a date-of-seeding trial, hand-seeded on a new clearcut, first and second year clover plant establishment averaged 1.5 and $0.2 \%$ respectively for 4 winter seedings (November 11 to March 22) compared to 18.3 and $13.2 \%$ for a May seeding. First and second year establishment of orchardgrass in winter seedings was $\mathbf{4 2 . 1}$ and 21 .9\% compared to 35.6 and $12 \%$ for the May seeding. These results indicate that while broadcast seeding on snow-covered high elevation clearcuts resulted in successful establishment of some erasses, it was ineffective for establishment of alsike and white clover.

Key Words: clearcut revegetation, snow seeding, lezume mortality

Clearcut logging in Interior British Columbia can cause significant soil disturbance which may result in soil erosion, but the logging may also create a seedbed suitable for broadcast seeding of domestic forages. Establishment of forage grass and legume species may reduce the erosion potential (Troughton 1957, Hughes et al. 1985, Waldron and Dakessian 1982) while supplementing domestic and wildlife forage supply.

Traditionally, aerial seeding of clearcuts in British Columbia was done in February and March, on the snow, with apparent success [M.T. Wallace, B.C. Ministry of Forests and Lands (BCMFL), pers. comm.]. Eventually however, field staff observed that legume establishment on winter seedings was not as good as that on areas hand-seeded in other seasons (D.F. Brooke, BCMFL, pers. comm.).

The literature contains few reports of this type of winter seeding. Anderson and Elliott (1957) sowed a grass-legume mixture in plots on burned-over sites in northern British Columbia in late October and early April. Autumn seedings were done on 7.5 to $15 \mathrm{~cm}$ of snow, while spring seedings were carried out "before all the snow had disappeared."Seeding date did not affect grass establishment, but spring seeding gave better legume establishment, measured in the second year after seeding. Renteria (1967) used a helicopter to sow a grass-alfalfa mix onto snow on 200 ha of southwest slopes at $1,260 \mathrm{~m}$ elevation in Washington in late January. Although he reported observing a strong stand of orchardgrass by the fall of the first year, he made no reference to successful alfalfa establishment. Bleak (1959) and Hull (1960) placed grass seeds under high eleva-

\footnotetext{
Authors are research technician, Agriculture Canada Research Station, 3015 Ord Road, Kamloops, B.C. V2B BA9; and associate professor, Department of Plant Science, University of British Columbia, Vancouver, B.C. V6T 2 A2.

Research was funded in part by an operating grant from Agriculture Canada.

Manuscript accepted 22 September 1987.
}

tion snow packs, then removed and tested samples at intervals throughout winter and spring. In both experiments, grass seeds were able to survive and some germinated in the thawed soil under the snow. There are no reports of success in sowing legumes on snow.

There is, apparently, little published information to support an a priori assumption that legumes are less able to survive seeding onto the winter snowpack. The objective of this investigation was to determine the effect of seeding date on the establishment and survival of some domestic grasses and legumes. The studv reported here was conducted in 2 phases; a survey of species' establishment on operational seedings, followed by a date-of-seeding trial on a recent clearcut. In each phase, relative species performance was evaluated in relation to seeding date.

\section{Materials and Methods}

\section{Grass and Clover Establishment in Operational Seedings}

The objective of this part of the study was to determine whether operational winter seeding was related to a significant reduction in clover establishment. Although the literature gave no reason to suspect the hardiness of alsike and white clover (Elliott and Bolton 1970) there were no establishment data for introduced grasses or legumes on clearcuts in this region. A simple comparison of the relative establishment on winter seedings of the 5 species in the seed mix was not sufficient. Spring-seeded sites were used to provide a comparative estimate of species establishment.

\section{Study Area/Operational Seeding Sites}

The study was restricted to seedings on logged sites above approximately $1,000 \mathrm{~m}$ elevation, in the Englemann sprucesubalpine fire (ESSF) biogeoclimatic zone (Krajina 1965). The seed mix most recently used in this zone contained, by numbers, $30 \%$ each of orchardgrass (Dactylis glomerata L.) and of timothy (Phleum pratense L.); 10\% smooth brome (Bromus inermis Leyss.) and $15 \%$ each of alsike clover (Trifolium hybridum $\mathrm{L}$.) and white clover (T. repens L.). Previously a mix termed "Forest Land"(FL) was used. It was similar to the ESSF mix except that alsike clover was the only clover component.

In the summer of 1979 sites were selected north and south of Kamloops and south of Merritt, B.C., an area spanning $210 \mathrm{~km}$. Winter-seeded stands were evaluated on 6 clearcuts situated in the ESSF zone. After completion of logging operations, all of the clearcuts had been drag-scarified to promote germination of conifers. The scarifier consisted of a heavy boat-anchor chain with protruding bars welded to each link. This unit was drawn over the clearing with a bulldozer. After scarification the sites had been inspected and found to have adequate seedbed preparation. Seeding was done during February and March, when the snowpack depth was typically at least $50 \mathrm{~cm}$ (Province of B.C. 1980). The seed was broadcast at $4.5 \mathrm{~kg} /$ ha with a crop-duster type single-engine aeroplane equipped with a venturi-tube dispensor. Spring-seeded log-landing areas, which had been sown with a Cyclonel seeder, on 2 sites in the adjacent Interior Douglas-Fir (IDF) zone (Krajina 1965) were available for comparison to the winter seedings. Although the IDF zone is generally drier, the latter sites had been seeded with the same ESSF seed mix, at $11.2 \mathrm{~kg} / \mathrm{ha}$. Five landings were sampled on each site. Site descriptions and seeding dates are summarized in Table 1.

Mention of the product name does not constitute an endorsement. 
Table 1. Site conditions, and seeding treatment on locged areas evaluated in 1979 in the Kamloops region of Britiah Columbia.

\begin{tabular}{|c|c|c|c|c|c|c|}
\hline Site & $\begin{array}{l}\text { Elevation } \\
\text { (m) }\end{array}$ & $\begin{array}{l}\text { Seeding } \\
\text { date }\end{array}$ & Seed mix & $\begin{array}{l}\text { Seeding rate } \\
(\mathrm{kg} / \mathrm{ha})\end{array}$ & $\begin{array}{l}\text { Seedbed prepara- } \\
\text { tion }(\%)\end{array}$ & Topography \\
\hline $\begin{array}{l}\text { Clearcuts: } \\
\text { Grace Lake }\end{array}$ & 1480 & $1977(W)^{\prime}$ & FL & 4.5 & 37 & Level to moderately sloping \\
\hline Andrew Lake & 1540 & $1977(W)$ & FL & 4.5 & 42 & Steep cast slope \\
\hline Miner Creek & 1450 & $1977(w)$ & FL & 4.5 & 42 & $10 \%$ northeast slope \\
\hline Dardanelles Lake & 1450 & $1977(W)$ & FL & 4.5 & 63 & Steep east slope \\
\hline Wyse Lakes & 1500 & $1979(W)$ & ESSF & 4.5 & 30 & Fairly level/much logging debris \\
\hline Prospect Creek & 1100 & $1979(W)$ & ESSF & 4.5 & 36 & North slope/mineral soil \\
\hline $\begin{array}{l}\text { Landings: } \\
\text { Orchard Lake }\end{array}$ & 890 & May $8,1978(S)$ & ESSF & 11.2 & 100 & Level to moderate sloping \\
\hline Barnes Creek & 1170 & June $6,1978(S)$ & ESSF & 11.2 & 100 & Level to moderate sloping \\
\hline
\end{tabular}

'Letter in brackets gives season of seeding ( $W=$ winter; $S=$ spring).

\section{Transects}

At each site a transect was established across the area, and a quadrat frame was place along 1 side at 2 or $4-\mathrm{m}$ intervals. The $4 \mathrm{~m}$ interval was used on landings because they were more homogeneous in seedbed quality and in stand establishment than were clearcuts. Clover, orchardgrass, timothy, and smooth brome plants rooted within the frame were counted and the proportion of the area within the frame having acceptable seedbed preparation (scarification) was recorded. The acceptable seedbed category in this survey included bare mineral soil, mineral mixed with organic material, and occasionally nearly-pure organic material with a good moisture supply. Thick layers and ridges of coarse organic matter, which was predominately needle litter, were excluded from this category.

In the clearcuts, which averaged 20 ha in area, $100 \mathrm{~m}$ long, 50 -quadrat transects were used. On landings, which averaged 0.8 ha, $40 \mathrm{~m}$ long, 10-quadrat transects were used. To facilitate counting, a 1-m² plot was used on sparse stands; a $0.1-\mathrm{m}^{2}$ plot was used on dense stands (Orchard Lake, Grace Lake, Miner Creek, Table $1)$.

Species success was expressed as the percent of those live seeds, which had apparently landed on a suitable seedbed, producing established plants. This method removed the variability arising from the use of different seed mixes and seeding rates, and from site conditions. This was done by dividing the number of plants by the number of live seeds applied and dividing that value by the mean proportion of seedbed on the transect. After these adjustments, there remained a large range in variances for the species, so analysis of variance was performed on $\log$ transformed data. Sample size for winter and spring seedings was 300 and 100 respectively. Therefore the critical range in each comparison of means (Duncan's new multiple range test) was adjusted for the number of replicates for each mean (Kramer 1956). The data reported are de-transformations of these means.

\section{Effect of Seeding Date on Grass and Clover Establishment}

To establish a basis for interpretation of survey findings, a date-of-seeding trial was established on a single clearcut located 12 $\mathrm{km}$ east of the city of Kamloops, at 1,445 m elevation on the north side of Lolo Mountain. The clearcut, about 29 ha in area, was on a hummocked, $10 \%$ slope, facing northeast. The forest on the site had been a young (about 87 years) homogeneous, healthy stand of lodgepole pine. The timber was harvested during the winter of 1978-79 and the site was drag-scarified in November, 1979. There was a relatively small amount of windfall on the site because of the good health of the original pine forest. As a result, an evenly and thoroughly scarified seedbed was obtained.

The experiment consisted of 5 treatments replicated 4 times in a randomized complete block design. Treatments (seeding date) included seeding before the first snowfall, 3 seedings on the snowpack, and 1 seeding after spring melt. Establishment and survival were evaluated in the 2 years following seeding.

The seed mix used was based on the ESSF mix, modified to contain equal numbers of each species: orchardgrass, timothy, smooth brome, alsike, and white clover. Plots were seeded at 4.5 $\mathrm{kg} / \mathrm{ha}$, the rate for operational aerial seedings. Immediately prior to seeding, legumes were inoculated with Rhizobium trifolii at 6.8 $\mathrm{g} / \mathrm{kg}$ alsike and $12.5 \mathrm{~g} / \mathrm{kg}$ white clover, using milk as adhesive. For each plot the clover was weighed out, inoculated and then added to the grass complement.

Each seed lot was sufficient to cover the $6 \times 1.5-\mathrm{m}$ plot, plus a 0.5-m wide buffer strip on all sides. Seedings were done on 11 November, 1 and 24 February, 22 March, and 2 May. Seed was broadcast by hand over the plot and the buffer strip without disturbing the surface of the snow on the plot. Each block was fenced to exclude cattle. During the establishment year, seedling counts of all species were made on the $9 \mathrm{~m}^{2}$ area of each plot. Germination and growth of native grasses (apparently mainly Bromus vulgaris (Hooker) Shear, Hitchcock and Cronquist 1961) precluded accurate identification of the smooth brome component of the mixture; observation of the latter species was subsequently discontinued as a consequence of this identification problem. Some clover plants were extremely small and insufficiently developed to allow species differentiation. Such plants were assigned to a "stunted" clover class in the data summary.

In 1981, labor shortage necessitated estimation of second year survival by using a sample population in each plot. $A 0.25-\mathrm{m}^{2}$ hoop was placed 4 times, at 1.25-m intervals down the centre of the plot. Only orchardgrass and the clovers were counted. An arbitrary classification of relative vigor was used in which "strong" plants were considered to be established and able to compete successfully in the existing plant population, while those judged to be "weak" were small (orchardgrass, $<15 \mathrm{~cm}$; clovers, $<5 \mathrm{~cm}$ tall) and chlorotic.

ANOVA was done on number of plants per $\mathrm{m}^{2}$, assuming a randomized block design, to determine effects for date of seeding, species, species $X$ date, and species $\times$ block. Effect of date of seeding within species $X$ year of observation was reanalyzed and the means were compared by Duncan's new multiple range test, then presented as percent establishment of the live seeds sown.

\section{Results}

\section{Operational Seedings}

The survey of logged sites confirmed that clover establishment on operational winter seedings was inferior to that obtained on spring seedings where 26 times more of the clover seeds survived to produce plants (Table 2). Poor clover performance was not a 
Table 2. Effect of season of seeding on eatablishment' of grasaes and clovers wown on lozzed sites by the B.C. Ministry of Forests and Lands.

\begin{tabular}{lcc}
\hline Species & $\begin{array}{c}\text { Winter aerial } \\
\text { seeding on } \\
\text { clearcuts }\end{array}$ & $\begin{array}{c}\text { Spring hand } \\
\text { seeding on } \\
\text { landings }\end{array}$ \\
\hline Alsike and white clover & Percent establishment of live seeds sown \\
\cline { 2 - 3 } Orchardgrass & $0.1 \mathrm{~d}^{4}$ & $2.6 \mathrm{a}$ \\
Timothy & $2.3 \mathrm{a}$ & $1.3 \mathrm{~b}$ \\
Smooth brome & $1.2 \mathrm{~b}$ & $0.5 \mathrm{c}$ \\
\hline
\end{tabular}

'Plant counts were done during the summer of 1979 on clearcuts seeded in 1977 through 1979 and on landings reeded in 1978.

${ }_{2}$ Values are means for 50 plots along a $100 \mathrm{~m}$ transect on each of 6 clearcut logged sites $(\mathrm{n}=300)$. Plots were $1 \mathrm{~m}^{2}$ on all but 2 sites with dense stands where they were $0.1 \mathrm{~m}^{2}$. 3Values are the means for 10 plots along a $40 \mathrm{~m}$ transect in each of the 5 landings on 2 selectively logged areas $(n=100)$. Plots were $0.1 \mathrm{~m}^{2}$ where stands were dense and $1 \mathrm{~m}^{2}$ at all other locations.

${ }^{4}$ Means followed by the same letter are not significantly different $(P \leq 0.05)$.

consequence of lack of adaptation of the species to the area since, in spring-seeded stands, both white and alsike clover performed at least as well as all grass species. Winter seeding did not reduce grass establishment; winter seedings of orchardgrass, timothy, and smooth bromegrass all produced stands equal to or better than those of the spring seedings.

\section{Establishment on Landings}

Landing sites were generally compacted, with a seedbed of mineral soil mixed with gravel and rock. Only one Orchard Lake landing had been scarified before seeding. At Barnes Creek, 2 of the landings were covered with a thick layer of bark and other organic matter, giving a loose-textured seedbed. On these sites, grazing by cattle in 1979 had been very heavy, and several plants had been uprooted. In both sampling areas, all seeded species sown in 1978 flowered in 1979 and were producing a usable amount of forage.

\section{Establishment on Clearcuts}

Small populations of all species at Wyse Lakes appeared to be partly due to poor scarification. At this site, there was a large volume of windfall and logging waste material preventing seed from landing on the soil, and much of the native root mat was undisturbed. However, degree of site scarification was not the only factor in the low degree of clover success. The best clover establishments (0.4 and $0.2 \%$, after correction), were achieved at Dardanelles Lake and Wyse Lakes respectively, with 63 and $30 \%$ respectively of the logged area scarified to form a good seedbed.

\section{Winter Date-of-Seeding Plot Trial}

\section{First-Year Establishment}

May seedings of both clover species produced significantly denser stands $(P \leq 0.05)$ than did seedings in November, February, and March (Table 3). Date of seeding had no effect on the establishment of orchardgrass and (with the exception of $22 \mathrm{March}$ ) on that of timothy.

Part of the variation in first-year establishment was apparently a consequence of differences in adaptation of each species to this site; in the May (control) seeding, the orchardgrass establishment was more than twice that of white clover (Table 3). White clover establishment averaged over all seeding dates was less than that of alsike ( $P \leq 0.05$; analysis not shown).

In this trial the May seeding represents the optimum conditions for broadcast seeding and therefore could be expected to have the higest establishment values, against which the others can be measured. However, sowing at this favorable time did not remove some barriers to establishment which typify clearcut seeding, e.g., the poor seedbed and the lack of coverage after seeding. These factors resulted in $18.4 \%$ average first-year establishment of the clovers sown in May. It can be assumed that this maximum establishment ceiling would have also applied to those seeds sown during winter.
Table 3. Effect of seeding date on first and second year eatabliahment of clover and grass species hand seeded on Lolo Mountain during the winter of 1979-1920.

\begin{tabular}{|c|c|c|c|c|c|}
\hline \multirow[b]{2}{*}{ Species } & \multicolumn{5}{|c|}{ Seeding date } \\
\hline & Nov. 11 & Feb. 1 & Feb. 24 & Mar. 22 & May 2 \\
\hline & \multicolumn{5}{|c|}{ Percent establishment of live seeds sown 1} \\
\hline $\begin{array}{c}\text { Alsike clover: } \\
\text { 1980-total }\end{array}$ & $3.3 \mathrm{~b}$ & $1.9 \mathrm{~b}$ & $1.6 \mathrm{~b}$ & $0.3 \mathrm{~b}$ & $23.0 \mathrm{a}(\mathrm{st})$ \\
\hline $\begin{array}{l}\text { 1981-strong } \\
\text { 1981-total }\end{array}$ & $\begin{array}{l}0.3 \mathrm{~b} \\
2.2 \mathrm{~b}\end{array}$ & $\begin{array}{l}0.9 \mathrm{~b} \\
1.9 \mathrm{~b}\end{array}$ & $\begin{array}{r}0 \mathrm{~b} \\
0.6 \mathrm{~b}\end{array}$ & $\begin{array}{l}0 \mathrm{~b} \\
\mathbf{0} \mathbf{b}\end{array}$ & $\begin{array}{l}21.8 \mathrm{a} \\
23.4 \mathrm{a}\end{array}$ \\
\hline $\begin{array}{l}\text { White clover: } \\
\text { 1980-total }\end{array}$ & $2.3 \mathrm{~b}$ & $0.7 \mathrm{~b}$ & $0.9 \mathrm{~b}$ & $0.7 \mathrm{~b}$ & $13.7 \mathrm{a}(\mathrm{t})$ \\
\hline $\begin{array}{l}\text { 1981-strong } \\
\text { 1981-total }\end{array}$ & $\begin{array}{c}0 \mathrm{~b} \\
3.8 \mathrm{ab}\end{array}$ & $\begin{array}{r}0 \mathrm{~b} \\
1.3 \mathrm{~b}\end{array}$ & $\begin{array}{r}0 \mathrm{~b} \\
0.6 \mathrm{~b}\end{array}$ & $\begin{array}{l}0 \mathbf{b} \\
0 \mathbf{b}\end{array}$ & $\begin{array}{l}4.4 \mathrm{a} \\
7.0 \mathrm{a}\end{array}$ \\
\hline $\begin{array}{l}\text { Stunted clovers: } \\
\text { 1980-total }\end{array}$ & $5.3 \mathrm{~b}$ & $2.7 \mathrm{~b}$ & $3.3 \mathrm{~b}$ & $0.5 \mathrm{~b}$ & $11.3 \mathrm{a}$ \\
\hline 1981-total & $1.6 \mathrm{a}$ & $0.5 \mathrm{a}$ & $0.9 a$ & $0.2 \mathrm{a}$ & $0.2 \mathrm{a}$ \\
\hline $\begin{array}{l}\text { Orchardgrass: } \\
\text { 1980-total }\end{array}$ & $44.1 \mathrm{a}$ & $34.8 \mathrm{a}$ & 50.3 a & $39.3 \mathrm{a}$ & $35.6 \mathrm{a}(\mathrm{s})$ \\
\hline $\begin{array}{l}\text { 1981-strong } \\
\text { 1981-total }\end{array}$ & $\begin{array}{l}24.1 \mathrm{a} \\
25.6 \mathrm{a}\end{array}$ & $\begin{array}{l}19.6 \mathrm{a} \\
22.8 \mathrm{a}\end{array}$ & $\begin{array}{l}29.4 \mathrm{a} \\
32.0 \mathrm{a}\end{array}$ & $\begin{array}{l}14.6 \mathrm{a} \\
16.8 \mathrm{a}\end{array}$ & $\begin{array}{l}12.0 \mathrm{a} \\
16.5 \mathrm{a}\end{array}$ \\
\hline $\begin{array}{l}\text { Timothy: } \\
\text { 1980-total }\end{array}$ & $21.0 \mathrm{a}$ & $14.6 \mathrm{ab}$ & $15.3 \mathrm{ab}$ & $9.0 \mathrm{~b}$ & 22.3 a (st) \\
\hline
\end{tabular}

IValues are $\bar{x}$ for four $9 \mathrm{~m}^{2}$ plots. For each species 79 germinable seeds $/ \mathrm{m}^{2}$ were sown; the numerator for \% calculations for stunted clovers is 158 seeds of the 2 species per $\mathrm{m}^{2}$. Means within rows followed by the same letter $(a, b)$ are not significantly different $(P \leq 0.05)$

"For the identified clovers and orchardgrass these are the counts of the "strong" plants, $\geq 5$ and $\geq 15 \mathrm{~cm}$ tall respectively.

${ }^{3}$ Values are the sums of those plants described in Footnote 3 plus the counts of the smaller but identifiable plants.

'Means for the 1980 total counts for the May seeding followed by the same letter $(s, t)$ are not significantly different $(P \leq 0.05)$.

The contribution of winter conditions to seed mortality can be isolated. For instance, the average clover establishment on winter seedings was $1.5 \%$ of the seeds sown (Table 3; alsike and white, 1980 , November-March seedings). Those seeds which survived to produce plants had been exposed to the barriers imposed by winter conditions and then by site conditions in the spring. The $1.5 \%$ value is actually $18.4 \%$ of the number of seeds alive at the beginning of spring, so theoretically $8.1 \%$ of the clover seeds sown $[(1.5 \div$ 18.4)100] survived winter.

Timothy establishment was equal to that of orchardgrass on the spring-seeded plots (Table 3), but it was significantly poorer on all others ( $P \leq 0.05$; analysis not shown). Seeding on $22 \mathrm{March}$ was least effective, producing only $41 \%$ of the timothy catch obtained with May seeding (seeding in March was also the most damaging for clover seed, although the effect was not significant at $P \leq 0.05$ ). These data suggest that timothy seed may incur some damage during winter conditions, in contrast to the operational survey where establishment of this species was greater on the winterseeded clearcuts than on the spring-seeded landings (Table 2).

\section{Second-Year Survival}

The 3 species evaluated in the second year all showed mortality (Table 3) which, over the 5 treatments, averaged 14\% reduction in total plant count for alsike clover, $42 \%$ for white clover, and $46 \%$ for orchardgrass. Only timothy flowered in the first year, whereas all 5 species in the trial flowered in the second year.

An interaction ( $P \leq 0.05$; analysis not shown) was observed between species response and seedbed characteristics on the blocks (Table 4). Among the 4 blocks, alsike establishment was best on number one, whereas white clover establishment was poorest there. On block number 1 the log landing activities had left the area with an extremely well-compacted soil surface relative to that on the other 3 blocks. During early May of 1980 there was little 
Table 4. Effect of block soil characteriatics on first and second year eatablishment of clovers and orchardgrass, hand-seeded on Lolo Mountain during the winter of 1979-1980.

\begin{tabular}{|c|c|c|c|c|c|c|c|c|}
\hline \multirow[b]{2}{*}{ Species } & \multicolumn{2}{|c|}{$\begin{array}{c}\text { Compacted } \\
\text { log landing } \\
\text { (1) }\end{array}$} & \multicolumn{2}{|c|}{$\begin{array}{c}\text { Deep } \\
\text { organic soil } \\
(2) \\
\end{array}$} & \multicolumn{2}{|c|}{$\begin{array}{l}\text { Gravelly } \\
\text { ridge top } \\
\text { (3) }\end{array}$} & \multicolumn{2}{|c|}{$\begin{array}{l}\text { Gravelly } \\
\text { ridge top } \\
\text { (4) }\end{array}$} \\
\hline & 1980 & 1981 & 1980 & 1981 & 1980 & 1981 & 1980 & 1981 \\
\hline & \multicolumn{8}{|c|}{ Percent establishment of live seeds sown } \\
\hline $\begin{array}{l}\text { Alsike clover } \\
\text { White clover } \\
\text { Orchardgrass } \\
\text { Timothy }\end{array}$ & $\begin{array}{r}8.71 \\
2.0 \\
55.7 \\
13.9\end{array}$ & $\begin{array}{c}9.2 \\
1.9 \\
5.3 \\
\text { NE}^{2}\end{array}$ & $\begin{array}{r}7.1 \\
3.9 \\
45.1 \\
24.8\end{array}$ & $\begin{array}{r}5.6 \\
3.4 \\
41.5 \\
\text { NE }\end{array}$ & $\begin{array}{r}5.1 \\
11.5 \\
27.0 \\
14.4\end{array}$ & $\begin{array}{r}4.5 \\
5.1 \\
19.5 \\
\text { NE }\end{array}$ & $\begin{array}{r}4.4 \\
4.1 \\
41.8 \\
17.8\end{array}$ & $\begin{array}{r}4.3 \\
2.1 \\
28.1 \\
\text { NE }\end{array}$ \\
\hline
\end{tabular}

IValues are means for 5 seeding dates. Observations for 1980 were made on the entire 9 $\mathrm{m}^{2}$ plot, those for 1981 were made on four $0.25 \mathrm{~m}^{2}$ samples per plot. Both values are total plant counts, and therefore include both strong and weak individuals.

2NE: this species not evaluated in 1981.

precipitation on Lolo Mountain, therefore, moisture supply appeared to be an important factor during the germination and early establishment period. In the second year, alsike plant density on block 1 did not drop, with most plants showing good vigor. Although most white clover plants also survived, only one-third of them showed vigorous growth. Orchardgrass first-year establishment was successful on block one $(55.7 \%$ of the seeds sown produced plants) although the seedlings were only $20 \%$ of the average plant height on other blocks (data not shown). These plants never recovered from this poor start; in the second year only 5.3\% remained and all were very small and chlorotic. Poor grass performance on this landing may be consistent with the lower rates of establishment (compared to that of clover) observed for orchardgrass and timothy on the spring-seeded landings included in the operational survey (Table 2). Although none of the latter sites had as poor a seedbed as the Lolo site (judged by the vigor of the grass), there may have been soil compaction sufficient to reduce percent establishment.

\section{Discussion}

\section{Operational Seedings}

The survey of operational seedings revealed the very low percentage of seeds that result in established plants in operational broadcast seedings on logged sites. The values shown in Table 2 are corrected for the area of seedbed available (for this investigation, landings were considered to have $100 \%$ available seedbed). On the clearcut areas, an average of only $42 \%$ of the soil surface could be considered satisfactory seed bed, therefore values for actual establishment would be $42 \%$ of those shown. For instance, the actual establishment observed on the clearcut sites was: orchardgrass $1.0 \%$, timothy $0.5 \%$, smooth brome $0.5 \%$, and alsike clover $.04 \%$. These results are in sharp contrast to establishment observed on seed drilled into a cultivated and irrigated plot for these species respectively, $56,65,99$, and $94 \%$. The plot was located $4.5 \mathrm{~km}$ northeast of Kamloops at $1,138 \mathrm{~m}$ elevation (D.G. Stout, unpublished data 1986).

Accurate, uniform seed distribution is difficult to attain on landings using a hand-operated seeder and in aerial seedings of mountain cut blocks. Survey results must, therefore, be evaluated with some caution. Our interpretation of survey data is predicated upon the assumption that the components of the seeded mixture were relatively uniformly distributed during seeding and that the grass component may provide a satisfactory internal standard. Seedlings of all species were observed to be present at all sites examined.

Although many of the winter-seeded clovers were weak, vigorous plants were present on every site examined, often in close proximity to weaker represenatives. High elevation did not appear to limit the range of alsike clover as healthy plants, flowering and setting seed, were found at sites above $2,000 \mathrm{~m}$. While the ability to mature and reseed is neither essential, nor necessarily desirable on a clearcut site, the occurrence of nearly mature clover plants is a reflection of general species adaptation for use at these elevations.

\section{Date of Seeding Trial}

The value of this plot trial as a reflection of the operational seedings can be assessed by comparing establishment values for seeding done in the same season. The operational clearcut seeding had been carried out in late winter so the February/March seeding data (Table 3) on Lolo Mountain were used to calculate values of 23.9 and $1.3 \%$ establishment for orchard grass and clovers respectively (all 1981 survivors; for clovers, the mean of alsike and white, plus the value for stunted clovers). The corresponding values for the operational winter seedings (Table 2) are 2.3 and $0.1 \%$ establishment for orchardgrass and the clovers, respectively. Superior overall establishment was obtained in the plot experiment but the large difference between grass and clover survival of winter seeding was observed on both clearcuts and plots. The clearcut survey results were corrected for the observed degree of soil scarification, but no attempt was made to compensate for variation in slope or other site-specific characteristics. Four of the 6 clearcuts sampled were situated on areas with more severe slope than that on any part of the Lolo Mountain experimental plot area and it is possible that this factor decreased the percent establishment on the clearcuts. The plots at Lolo Mountain were situated on nearly level ground with a high degree of scarification to facilitate establishment of seeds that did not die during the winter. Seedbed selection was specifically intended to minimize confounding by other variables in a trial designed to investigate mortality caused by seeding on snow.

While not contributing to the established stand, the populations of stunted clover plants showed a response to seeding date analogous to that of normal, identifiable clovers; May seeding produced a greater stand density than did winter seedings. Since stunted plants were also observed in the spring seeding, seed quality (e.g., harvest and cleaning damage) and spring soil conditions may have contributed to the observed effect. However, these factors are not likely to have been the only causes. It can be argued that winter mortality should be equal in seeds planted at the same time regardless of any predisposition to subsequent stunting. The data presented (Table 3), however, suggest that winter conditions caused damage leading to the production of stunted seedlings; winterseeded plots contained more stunted clover seedlings than healthy plants of both alsike and white clover combined.

Although seeding date had no effect on the initial establishment of orchardgrass, by the second summer stands could be classified into 2 groups. November and February seedings retained $50 \%$ of their initial populations, while on the March and May seedings only about $30 \%$ of the original plants persisted (Table 3 ). The reason for this difference is unclear, although it is possible that the moisture supply was limiting on these areas by the time the soil warmed sufficiently to promote germination. Therefore, those seeds which were able to germinate and grow roots into the available soil water would have been most successful. Seeds of some cold-tolerant species can be induced to germinate at temperatures below their normal limit by prolonged cold moist stratification, such as that observed by Bleak (1959) and Hull (1960), who found grass seeds germinating under a snowpack. In the Lolo Mountain trial it is not inconceivable that the earlier seedings were, in effect, similarly stratified and able to germinate at a lower temperature in spring than were those that had been sown in March and May. Such an early start could have given these plants an advantage in survival during the first winter. This conjecture, however, assumes that the 41-day period between 22 March and 2 May was insufficient to have a stratification effect on the March-sown orchardgrass seeds. In the one-time seedings of a perennial pasture, longterm persistence of the stand is critical. The results of this trial suggest that winter seeding may be superior for orchardgrass establishment. 
Landing sites represent a unique post-logging revegetation challenge (Carr 1987). Such areas are generally deficient in nutrients, may be more susceptible to water erosion, and are subjected to increased grazing pressure after revegetation because of their accessibility. Landing sites and road cuts are often seeded on selectively logged areas where no other seeding may be justified.

The superior performance of legumes on the Lolo Mountain landing is noteworthy. The date-of seeding trial results are in agreement with those for the landings in the operational seeding survey (Table 2) where clover establishment was significantly better than that of orchard grass and timothy. The inability of the grass roots to establish in the compacted soil at Lolo Mountain may have been the cause of the failure, with the tap roots of the clovers successfully penetrating to reach sufficient water for establishment. Root structure allowed the clovers to maintain this advantage through the second year by anchoring the plants against erosive forces, while many of the surviving orchardgrass plants were attached by only 1 or 2 fibrous roots.

The clover plants clearly demonstrated another legume advantage on this type of site: their ability to fix atmospheric nitrogen. The pale color of the orchardgrass plants indicated that the nitrogen supply was limiting, but the clover plants, except those that were stunted, were vigorous and had good color. Nitrogen deficiency may have been a significant contributing factor to the low survival rate of the orchardgrass.

Comparison of winter-seeded clearcut logged sites with springseeded log-landing areas showed that in operational winter seedings, clover establishment was only $3.8 \%$ of that attained in spring seedings. Date of seeding trials showed a similar response; seedings in November, February, and March were inferior to a May seeding in clover establishment. By the second year, these winter seedings had $8.5 \%$ of the total clover population and $1.1 \%$ of the strong plants observed on the May seeding. Orchardgrass establishment was satisfactory in all seedings. These results suggest that spring seeding is preferable to winter seeding to ensure establishment of all species in the seed mixes currently used for revegetating clearcuts in the Kamloops region.

\section{Literature Cited}

Anderson, C.H., and C.R. Elliott. 1957. Studies on the establishment of cultivated grasses and legumes on burned-over land in northern Canada. Can. J. Plant Sci. 37:97-101.

Bleak, A.T. 1959. Germination characteristics of grass seed under snow. J. Range Manage. 12:298-302.

Carr, W. 1987. The effect of landing construction on some forest soil properties: A case study. Forest Resource Development Agreement Report 003. Victoria, B.C.

Elliott, C.R., and L. Bolton. 1970. Licensed varieties of cultivated grasses and legumes. Agr. Canada Pub. 1405.

Hitchcock, C.L., and A. Cronquist. 1961. Vascular Plants of the Pacific Northwest. Univ. Washington Press, Seattle.

Hughes, H.D., M.A. Heath, and D.S. Metcalife. 1985. Forages. The science of grassland agriculture, 2nd ed. Iowa State Univ. Press, Ames.

Hull, A.C., Jr. 1960. Winter germination of intermediate wheatgrass on mountain lands. J. Range Manage. 13:257-260.

Krafina, V.J. 1965. Biogeoclimatic zones of British Columbia. Ecological Reserves Commission. Victoria, B.C.

Kramer, C.Y. 1956. Extension of multiple range tests to group means with unequal numbers of replications. Biometrics. 12:307-310.

Province of British Columbia. 1980. Snow survey measurements 1935-1980. Ministry of Environment, Inventory and Engineering Branch. Victoria, B.C.

Renteria, D. 1967. Aerial reseeding after logging. Unpublished report by Agency Range Manager, Bureau of Indian Affairs, Coulee Dam, Washington.

Troughton, A. 1957. The underground organs of herbage grasses, Bulletin No. 44. Commonwealth Bureau of Pasture and Field Crops, Hurley, Berkshire.

Waldron, L.J., and S. Dakessian. 1982. Effect of grass, legume, and tree roots on soil shearing resistance. Soil Sci. Soc. Amer. J. 46:894-899. 